\title{
Bilinen en eski çelişki
}

\author{
The oldest known paradox \\ Mete Kara@ Hayriye Koçanaoğulları Figen Yargucu Zinni@ Gonca Karabulut(i) \\ Ege Üniversitesi Tıp Fakültesi İç Hastalıkları Anabilim Dalı, Romatoloji Bilim Dalı
}

\section{Öz}

Psoriatik artrit (PsA) aksiyal ve periferik eklemleri etkileyen, cilt, tırnak, entezis yerlerini tutabilen, psoriasis hastalarında görülebilen, klinik olarak heterojen bir hastalıktır. Bu nedenle de PsA birçok hastalık ile karışabilmektedir. Cilt tutulumu PsA hastalarının \%15'inde eklem tutuluşundan sonra saptanabilmektedir. Bu da tanıda ve takipte zorluk yaratmaktadır. Periferik artrit ile başvuran ve anti siklik sitrüline peptit (anti-ccp) antikoru pozitif bir olgu ile PsA tanısının konulmasındaki zorluklara ve PsA'nın ayrıcı tanısını yapabilmek için de dikkatli ve detaylı bir anamnez ile iyi bir fizik muayene gerektiğine dikkat çekmeye çalıştık.

Anahtar Sözcükler: Psoriatik artrit, anti siklik sitrüline peptit antikor (anti-ccp), ayırıcı tanı.

\begin{abstract}
Psoriatic arthritis (PsA) is a clinically heterogeneous disease which can be seen in patients with psoriasis, affects the axial and peripheral joints and can involve skin, nail and enthesis. Therefore, PsA can be confused with many diseases. Skin involvement can be established after joint involvement in $15 \%$ of PsA patients. This creates difficulties in diagnosis and follow-up. We attempted to draw attention to the difficulties in the diagnosis of PsA in patients who present with polyarthritis and positive anti-cyclic citrullinated peptide (anti-ccp) antibody and also, we underline necessity of cautious and detailed history taking and good physical examination.
\end{abstract}

Keywords: Psoriatic arthritis, anti-cyclic citrullinated peptide (anti-ccp), differential diagnosis.

\section{Giriş}

PsA aksiyal ve periferik eklemleri etkileyen, cilt, tırnak, entezis yerlerini tutabilen psoriasis hastalarında görülebilen, spondiloartrit grubunda yer alan kronik inflamatuvar bir hastalıktır (1). PsA olgularının \%15'inde psoriasis gelişmeden önce eklem tutuluşu gelişebilir (2). PsA başlangıçta farklı klinik tablolar ile karşımıza çıkabilir. PsA kliniği diğer spondiloartrit grubu hastalıklarla karışabildiği gibi, romatoid artrit, gut, osteoartrit gibi diğer romatolojik hastalıklarla da karışabilmektedir. Periferik artrit ile başvuran ve anti siklik sitrüline peptit antikoru (anti-ccp) pozitif bir olgu sunulmuştur.

\section{Olgu}

Yirmi beş yaşında kadın hastaya, yedi yıl önce inflamatuvar karakterde bel ağrısı ile başvurduğu dış merkez üniversite hastanesi romatoloji kliniğindeki radyografik değerlendirmesinde sakroiliak eklem grafisinde sakroiliit saptanması üzerine ankilozan spondilit tanısı konulmuş. Hastaya sulfasalazin (SSZ) $2 \mathrm{~g} / g u ̈ n$ ve diklofenak sodyum $100 \mathrm{mg} / \mathrm{gün}$ tedavisi verilmiş.

\footnotetext{
Yazıșa Adresi: Mete Kara

Ege Üniversitesi Tıp Fakültesi, İç Hastalıkları Anabilim Dalı, Romatoloji Bilim Dalı

E-mail: metekara@gmail.com
}

Düzensiz aralıklarla takip olan hasta, iki yıl önce el küçük eklemlerinde ağrı nedeni ile başvurduğu başka bir merkezde romatoloji polikliniğine başvurmuş. Oligoartriti olan hastanın laboratuvar incelemelerinde romatoid faktör (RF) ve anti-ccp pozitif olması üzerine hastaya seropozitif romatoid artrit tanısı konulmuş ve hastanın tedavisine metotreksat eklenmiş. Bir yıl önce sağ el proksimal interfalangeal eklemlerde ağrı ve inflamatuvar bel ağrısı yakınması ile kliniğimize başvurdu.

Hastanın başvuru anında sağ el 2-4 proksimal interfalangeal eklemlerde artrit saptandı. Sakroiliak eklemde sakroiliak germe testleri olan FABERE (fleksiyon, abdüksiyon, eksternal rotasyon) sağda pozitif saptandı. Lokomotor dışı diğer sistemik fizik muayenesinde patolojik bulguya rastlanmadı. Başvuru anında bakılan laboratuvar testleri; eritrosit sedimantasyon hIzı (ESH):17 mm/saat, C-reaktif protein (CRP):1,05 mg/dl, RF<11,5 IU/mL, anti ccp $>200 \mathrm{U} / \mathrm{mL}$ olup diğer laboratuvar verileri olağan sınırlardaydı. Bilateral iki yönlü el grafisi ve sakroiliak eklem grafisi normal olarak izlendi. Sakroiliak manyetik rezonans görüntülemesinde unilateral aktif dönemde sakroiliit saptandı. Metotreksat $15 \mathrm{mg} /$ hafta ve SSZ $2 \mathrm{~g} / \mathrm{gün}$ tedavisine metilprednizolon $4 \mathrm{mg} / \mathrm{gün}$ ve indometazin $150 \mathrm{mg} / g u ̈ n$ eklendi. Spondiloartrit için eğitim verildi, egzersiz ve rehabilitasyon önerisi ile takibe alındı. Üç ay 
sonraki kontrolünde yakınmaları kaybolan hastanın steroid tedavisi kesildi ve diğer tedavisine devam edildi.

Hastanın altı ay sonraki kontrollerinde sağ el 2-3 proksimal interfalangeal eklemlerde artrit ve el tırnaklarında çok sayıda pitting saptandı. Asimetrik oligoartrit, inflamatuvar bel ağrısı ve pitting nedeni ile hasta psoriatik artrit olarak kabul edildi. Dirençli periferik artritleri nedeni ile metotreksat tedavisi kesilip leflunomid $10 \mathrm{mg} / \mathrm{gün}$ tedavisi başlandı. Hastanın periferik artriti ve bel ağrısı kontrole alınarak takibine devam edildi. Hastadan tıbbi verilerinin yayınlanabileceğine ilişkin yazılı onam belgesi alınmıştır.

\section{Tartışma}

PsA'da deri bulguları hastaların \%70'inde artrit gelişmesinden önce meydana gelir. Hastaların \%15'inde aynı anda deri ve eklem bulguları gelişebilir. Hastaların $\% 15$ 'inde psoriasis tanısı konulmadan önce PsA gelişmektedir (3). Psoriasisli hastaların \%50-56'sında tırnak tutulumu görülmektedir. Hastaların yaşam boyu izlenmesi halinde bu oranın \%80-90'lara yükseldiği bildirilmiştir (4). Bizim hastamıza eklem bulguları ortaya çıktıktan sonra tırnak bulgusu ile tanı konulabilmiştir.

PsA klinik olarak heterojen bir hastalıktır. Eklem tutulum şekli olarak beş alt tipe ayrılır (5). Bazı hastalarda birden fazla eklem tutulum şekli ortaya çıkabilmekte, bazen de farklı eklem tutulum şekline dönebilmektedir. İzole aksiyal hastalık, PsA hastalarının sadece \%2 ila \%4'ünde görülür (3). Radyografik tutulum ise PsA hastalarında \%40-70 görülmektedir. PsA hastalarının \%63'ünde poliartiküler tutulum, \%13'ünde oligoartiküler tutulum izlenmektedir (6). Bizim olgumuz el küçük eklemlerde oligoartrit ile başvurmuş olup, takip eden süreçte sakroiliit gelişmiştir.

PsA birçok hastalık ile karışabilmektedir. Poliartiküler seyirli hastalarda bunlardan bir tanesi de romatoid artrittir. İkisinin ayrımında romatoid faktör pozitifliği ayırt edici gözükse de PsA hastalarında \%5-16 RF pozitifliği görülmektedir. PsA hastalarında anti-ccp pozitifliği \%5 görülmektedir (7). Bizim olgumuzda da anti-ccp pozitifliği saptanmıştır. Romatoid artritte anti-ccp antikorlarının rollerine ilişkin bazı kanıtlar olmasına rağmen, anti-ccp antikorlarının PsA gelişiminde herhangi bir patojenik role sahip olup olmadığı belirsizdir (8). PsA hastalarında anticcp antikorlarının pozitif olması, romatoid artritte olduğu gibi erozyonun daha fazla olabileceğinin göstergesi olabilir. PsA tanılı bir hastada anti-ccp antikorları varsa, temel etkili ilaç tedavisinin hastalık sürecinin erken döneminde başlanması önerilmektedir (7).

PsA hastalarında spondiloartrit tutulumu çok baskın görülmez. PsA'te ankilozan spondilitten farklı olarak sakroiliit tek taraflı olabilir. Yine PsA'te ankilozan spondilitten farklı olarak radyografide spinal değişiklikler daha fazla asimetrik izlenebilir (2).

PsA, psoriasis gelişmeden önce meydana gelebilmekte olup heterojen bir kliniğe sahiptir. Bu da hastaların farklı tanılar ile izlenmesine neden olabilmektedir. PsA'in bu zengin kliniğinin farkında olmak ve ayırıcı tanıda PsA'i düşünmek gerekmektedir. PsA'in ayrıcı tanısını yapabilmek için de dikkatli ve detaylı bir anamnez ile iyi bir fizik muayene gerekmektedir.

\section{Kaynaklar}

1. Haroon M, FitzGerald O. Psoriatic arthritis: complexities, comorbidities and implications for the clinic. Expert Rev Clin Immunol 2016;12(4):405-16

2. Fitzgerald O, Elmamoun M. Psoriatic arthritis. In: Firestein G, Budd R, Gabriel SE, Mclnnes IB, O'Dell J (Eds). Kelley \& Firestein's Textbook of Rheumatology. 10th ed. Philadelphia: Elsevier; 2016:1285-308.

3. Gladman DD. Clinical features and diagnostic considerations in psoriatic arthritis. Rheum Dis Clin North Am 2015;41(4):569-79.

4. Rich P. An atlas of diseases of the nail. http://file.zums.ac.ir/ebook/10-An Atlas of Diseases of the Nail-Phoebe Rich Richard K. Scher-185070595X-Taylor Francis-2003-1.pdf. Accessed September 30, 2018.

5. Moll JM, Wright V. Familial occurrence of psoriatic arthritis. Ann Rheum Dis 1973;32(3):181-201. http://www.ncbi.nlm.nih.gov/pubmed/4715537. Accessed September 30, 2018.

6. Helliwell PS, Porter G, Taylor WJ, CASPAR Study Group. Polyarticular psoriatic arthritis is more like oligoarticular psoriatic arthritis, than rheumatoid arthritis. Ann Rheum Dis 2006;66(1):113-7.

7. Korendowych E, Owen P, Ravindran J, Carmichael C, McHugh N. The clinical and genetic associations of anti-cyclic citrullinated peptide antibodies in psoriatic arthritis. Rheumatology (Oxford) 2005;44(8):1056-60

8. Reparon-Schuijt CC, van Esch WJ, van Kooten C, et al. Secretion of anti-citrulline-containing peptide antibody by B lymphocytes in rheumatoid arthritis. Arthritis Rheum 2001;44(1):41-7. 